\title{
ZUHUD DALAM AL-QURAN
}

\author{
Rumba Triana \\ Dosen Tetap STAI Al Hidayah Bogor \\ email : azzam.rumba@gmail.com
}

HP. 081382069794

\begin{abstract}
Abstrak
Dalam ajaran Tasawuf terdapat praktek zuhud, dimana jalan hidup seorang sufi meninggalkan dunia, dan mengosongkan hati hanya untuk Allah. Cara hidup zuhud telah menjadi bagian penting dalam ajaran tasawuf, namun Ihsan Ilāhi Zhāhir menyebutkan bahwa konsep zuhud yang difahami oleh kaum sufi adalah konsep zuhud yang radikal, maka dengan ini perlu ditelusuri bagaimana konsep zuhud yang dijelaskan dalam Al-Quran.

Tulisan ini memakai metode library research untuk pencarian data sebagai bahan-bahan kajian dalam makalah ini, dengan memakai bukubuku bertemakan tasawuf dan zuhud, dan yang memiliki korelasi terhadap kajian dalam makalah ini. Kemudian penelitian ini juga melengkapi dengan penelusuran buku-buku tafsir untuk memberikan interpretrasi terhadap ayat-ayat yang terdapat dalam makalah ini.

Tasawuf merupakan khazanah ilmu dalam Islam, perkembangan tasawuf membawa dimensi khusus yang dianggap sebagai cara khas yang ada dalam Islam. Ibrahim Basyuni telah memilih empat puluh definisi tentang tasawuf yang diambil dari rumusan ahli sufi yang diambil pada abad III, meskipun definisi tersebut demikian banyak, belum didapati sebuah definisi yang mencangkup pengertian tasawuf secara menyeluruh.

Diantara ayat-ayat yang berkaitan dengan zuhud adalah pada Q.S. AlHadīd [57] : 20 dan 23, Q.S. Al-Qashāsh [28]: 77, dan Q.S. Al-Mā'idah [5]: 87. Dan dari empat ayat beserta tafsirnya, maka dapat diambil konsep zuhud dalam Al-Quran yaitu, kesederhanaan, kesabaran, wara', dan keseimbangan (tawāzun)
\end{abstract}

Keyword : Sufi, Tasawuf, Zuhud 


\section{A. Pendahuluan}

Saat Islam sudah mulai tumbuh dan berkembang maka tidak bisa terhalangi aktifitas Islam di banyak negara-negara yang bukan Arab menjalankan Islam sesuai kedekatan budaya yang ada dalam wilayahnya masing. Dua kutub besar telah memiliki pengaruh dalam peradaban keilmuan Islam, Hijaz dengan tradisi ilmu yang bersumber dari âtsar dan tidak rentan dari tumbuhnya pemikiran-pemikiran yang keluar dari mainstream Islam yang telah ada. Adapun wilayah Iraq dan sekitarnya sebagai sebuah wilayah yang dikenal memiliki pertumbuhan yang pemikiran Islam yang lebih variatif, baik dalam fikih yang terkenal dengan madzhab ra'yunya, dan ajaran-ajaran lainnya seperti munculnya aktifitas orang-orang sufi yang kemudian dikenal dengan ajarannya dengan nama tasawuf.

Dalam perjalanannya tasawuf pun terlibat pro dan kontra tentang ajaran dan keyakinannya, diawal pemikirannya yang hanya masuk dalam aktifitas ibadah dan mengosongkan dari aktifitas dunia, dan terus berkembang sampai kepada cara ibadah yang khas yang pada akhirnya menuai kontroversi. Penolakan ajaran ini pun berkembang disemua zaman hingga hari ini, bahkan sejak kemunculannya saja ajaran ini sudah mengalami penolakan. Sehingga tidak sulit untuk mencari refrensi-refrensi yang berbicara tentang tasawuf. Pada dekade abad ke-3 H, tasawuf sudah berkembang menjadi tren beragama baru bagi orang Islam, ditengah-tengah kejenuhan mereka terhadap dunia.

Dalam ajaran tasawuf terdapat praktek zuhud, dimana seorang sufi diharuskan meninggalkan dunia, dan mengosongkan hati hanya untuk Allah. Ihsan Ilāhi Zhāhir menyebutkan bahwa konsep zuhud yang difahami oleh kaum sufi adalah konsep zuhud yang radikal, karena "berlebih-lebihan dalam melaparkan diri, menelanjangkan diri, meninggalkan hal-hal yang halal, menyengsarakan diri, menyusahkan diri, menysiksa diri, membebani diri dengan sesuatu yang tidak mampu dipikulnya, mendatang mudarat, berlebih-lebihan dalam perintahperintah Allah SWT. dan larangn-larangany-Nya, menghadap ke haribaan Alla SWT. dan Rasul-Nya hinga sampai pada tarap menjauhi apa yang diperintahkan-Nya, mengharamkan apa yang dihalalkan-Nya, menghalalkan apa yang diharamkan-Nya, mengerjakan apa yang 
dilarang oleh Allah SWT dan Rasul-Nya." ${ }^{84}$ Maka dengan ini perlu ditelusuri bagaimana konsep zuhud yang dijelaskan dalam Al-Quran.

Tulisan ini memakai metode library research untuk pencarian data sebagai bahan-bahan kajian dalam makalah ini, dengan memakai buku-buku bertemakan tasawuf dan zuhud, dan yang memiliki korelasi terhadap kajian dalam makalah ini. Kemudian penelitian ini juga melengkapi dengan penelusuran buku-buku tafsir untuk memberikan interpretrasi terhadap ayat-ayat yang terdapat dalam makalah ini.

\section{B. Pengertian dan Hakikat Tasawuf}

Tasawuf merupakan khazanah ilmu dalam Islam, perkembangan tasawuf membawa dimensi khusus yang dianggap sebagai cara khas yang ada dalam Islam, tasawuf adalah wasilah (medium) yang ditempuh oleh seorang mukmin melalui proses upaya dalam rangka menghakikatkan syariat lewat thariqat untuk mencapai makrifat ${ }^{85}$ Menurut Abah Anom, tasawuf berpangkal pada pribadi Nabi Muhammad SAW. Gaya hidupnya sederhana, tetapi penuh kesungguhan. Akhlak Rasulullah SAW. tidak bisa dipisahkan dari kemurnian cahaya Al-Quran. Akhlak Rasulullah SAW itulah titik tolak dan titik perhentian cita-cita tasawuf Islam. ${ }^{86}$

Ilmu ini dinamai ilmu tasawuf mengingat secara morfologis (lughah) tasawuf berasal dari kata shafâ yang berarti bersih, jernih dan suci dari kotoran serta penuh dengan berbagai keteladanan dan bagi mereka emas tak lebih berharga daripada tanah lempung. Sedangkan arti tasawuf secara terminologi diuraikan secara baik oleh Sayyid Nur bin Sayyid Ali, "sebagai metode pendidikan spritual yang dianggap berada dalam derajat media temporal-transisional, yang direkam untuk memperkokoh keimanan, mencapai derajat ihsan, mensucikan jiwa (Tazkiyah Al-Nafs) dan memperbaiki hati (Ishlah Al-Qalb). Sehingga memudahkan seorang hamba beriman mentaati Allah dan mentaati Rasulullah. Secara ringkas Sa'id Hawa mendefinisikan tasawuf

${ }^{84}$ Ihsan Ilāhi Zhāhir, Darah Hitam Tasawuf Studi Kritis Kesesastan Kaum Sufi, Jakarta: Darul Haq, cet.3, 2006 M, Hlm. 1

${ }^{85}$ Jamaluddin Kafie, Tasawuf Kontemporer, Jakarta: Mutiara Al-Amin Prenduan, 2003, hlm.8

${ }^{86}$ Asep Salahudin, Abah Anom: Wali Fenomenal Abad 21 \& Ajarannya, Jakarta: Penerbit Noura Books, 2013, Hlm. 160, 
sebagai, "berjalan menuju Allah, dijalan yang ditentukan Allah, untuk mencapai ridha Allah. ${ }^{87}$

Baiquni menyebut kata tasawuf dengan arti suatu ilmu tentang kesucian diri dengan menetapkan hati dan raga untuk beribadah dan menghubungkan diri kepada Allah SWT, agar menjadi manusia yang sempurna (insan kamil). Sementara Nicholson dalam didalam sebuah makalah Kedudukan Tasawuf Dalam Islam, menyatakan bahwa terdapat lebih dari 78 pengertian tasawuf yang salah satu diantaranya mengandung arti Al-Shafấ yang berarti bahwa kegiatan dan fokus utama perbuatan atau amaliah tasawuf adalah proses mesucikan diri kita sebagai manusia yang beriman kepada Allah SWT., bebas dari keterikatan pada hal-hal yang menjauhkan manusia dari Allah Swt. ${ }^{88}$

Tasawuf adalah nama yang diberikan bagi mistikisme dalam Islam, yang oleh para orientalis Barat disebut sebagai sufism (sufisme). Kata sufisme dalam literatur barat, khusus dipakai untuk mistikisme Islam, (Islamic Mysticism) atau mistik yang tumbuh dalam Islam. Sufisme atau tasawuf (The Mystic Of Islam) tidak dipakai untuk mistikisme yang terdapat dalam agama lain, Dengan demikian jelas bahwa sufisme telah diakui oleh dunia barat sebagai mistik yang murni dalam Islam dan diakui telah memiliki sistematika keilmuan tersendiri. Sebagai kesimpulan, pengertian dari berbagai asal kata dan tradisi tasawuf itu, dalam kamus A.S. Hornby definisi tasawuf atau mistik, "Mistikisme adalah suatu ajaran atau kepercayaan bahwa pengetahuan tentang hakikat Tuhan bisa didapatkan melalui meditasi atau kesadaran spritual yang bebas dari campur tangan akal dan panca Indra." $" 89$

Selanjutnya pembicaraan seputar tasawuf, akan didapati perselisihan dalam asal penamaan, hakikat tasawuf, dan sejarah kemunculannya. Ibrahim Basyuni telah memilih empat puluh definisi tentang tasawuf yang diambil dari rumusan ahli sufi yang diambil pada abad III, meskipun definisi tersebut demikian banyak, belum didapati sebuah definisi yang mencangkup pengertian tasawuf secara

87 Ahmad Dimyati, Dakwah Personal: Model Dakwah Kaum Naqsanbadiyah, Yogyakarta: Penerbit Deepublish, 2016, Hlm. 20

${ }^{88}$ Rani Anggraini Dewi, Menjadi Manusia Holistik, Jakarta: Penerbit Hikmah, 2006, Hlm.102

89 Muhammad Solikhin, Filsafat dan Metafisika Dalam Islam: Sebuah Penjelajahan Pengalaman Mistik, Dan Perjalanan Aliran Manunggaling Kawula Gusti, Yogyakarta: Penerbit Narasi, 2008, hlm. 272 
menyeluruh. Hal ini kata Basyuni disebabkan oleh karena para ahli tasawuf tidak ada yang memberikan definisi tentang ilmunya sebagaimana filsuf. Ahli tasawuf hanya menggambarkan tentang suatu keadaan yang dialami dalam kehidupan ruhaninya pada waktu tertentu. Ibrahim Basyuni telah memilih empat puluh definisi tentang tasawuf yang diambil dari rumusan ahli sufi yang diambil pada abad III, meskipun definisi tersebut demikian banyak, belum didapati sebuah definisi yang mencangkup pengertian tasawuf secara menyeluruh. Hal ini kata Basyuni disebabkan oleh karena para ahli tasawuf tidak ada yang memberikan definisi tentang ilmunya sebagaimana filsuf. Ahli tasawuf hanya menggambarkan tentang suatu keadaan yang dialami dalam kehidupan ruhaninya pada waktu tertentu. ${ }^{\mathbf{9 0}}$

Ihsan Ilâhi Zhâhir seorang pakar madzab pemikiran dalam Islam menyebutkan bahwa para ilmuwan telah berbeda pendapat untuk mencari asal kata dari tasawuf atau sufi. Dengan menukil dari beberapa pendapat dari para sufi, pendapat-pendapat mengenai asal kata dari sufi adalah; Al-Shafä' (ketenangan), Shafwa, kemudian juga disebukan dinamakan sufi karena mereka adalah Shafā’ Asrār (bersihnya hati), Shifatullah, Shaff Al-Awwal, Ahlussuffah, Al-Shüf (pakaian wol). Kemudian menurut Ihsan Ilāhi sufi juga dipanggil dengan nama-nama lain yang berkesesuaian dengan sifat mereka, Ghurabā', Siyāĥ̄n, Syakafatiyyah (gua), Jü'iyyah, Fuqarā', Shüfiyyah, Nüriyyah. Dan inilah nama-nama yang dikenal telah dilekatkan kepada kelompok ini, sedangkan nama yang kemudian menjadi familiar yaitu dengan nama Shüfiyyah. ${ }^{91}$

Ibnu Taymiyyah menguatkan asal kata dari sufi, dengan sekaligus memberikan kritik atas kata-kata tersebut. Al-Shuffah, kata ini kaitkan dengan arti adalah bahwa orang-orang sufi adalah sekelompok kaum Muslimin yang tinggal disekitar masjid Nabawiy dan mereka bukanlah asli penduduk Madinah tapi para transmigran (muhäjirin) yang menetap disekitar Masjid Nabawi dikarenakan kemiskinan mereka sehingga mereka menetap disana. Ibnu Taymiyyah mengoreksi jika kata sufi berasal dari kata shuffah maka yang benar, mereka dinamakan dengan kata Shuffiyyah. Al-Shafä', maksud dari kata ini adalah bahwa meraka orang yang tenang dalam jiwanya dan baik dalam

90 Sokhi Huda, Tasawuf Kultural: Fenomena Shalawat Wahidiyah, Yogyakarta: LKiS Yogyakarta, 2008, hlm. 25

${ }^{91}$ Ihsan Ilâhi Dzâhir, Al-Tashawwuf Al-Mansya' Wa Al-Mashâdir, Pakistan: Idârah Tarjaman Al-Sunnah, 1406 H, Hlm. 20-36 
hal-hal yang rahasia. Namun Ibn Taymiyyah juga mengkritik kata ini, jika asal kata sufi dari kata $\mathrm{Al}$-Shafa ${ }^{\prime}$ 'maka yang benar mereka akan dinamakan dengan shafäiyyah atau shafwiyyah. Al-Shaff, yang dimaksud dengan kata ini sangat banyak, diantaranya shaff pertama dalam shalat. Ibn Taymiyyah menjelaskan jika yang dimaksud kata sufi dengan kalimah ini, maka seharusnya kalimat yang dipakai adalah shafiyyah. Al-Shüfah, kalimat ini muncul dari julukan seseorang yang yang bernama Al-Ghauts Ibn Mur, laki-laki ini dijuluki dengan $\mathrm{Al}$ Shüfah karena pada saat itu Al-Ghauts Ibn Mur menjadi pelayan di Kabah sendirian sehingga dengan itu ia dijuluki manusia dengan $\mathrm{Al}$ Shüfah. Menurut pandangan Ibn Taymiyyah kata ini yang tepat yang bisa dijadikan padanan kata untuk kata shüfi. ${ }^{92}$ Dari sudut pandang bahasa, tasawuf berasal dari kata shüf yang berarti kain yang terbuat dari kain wol. Pengambilan definisi ini erat kaitannya dengan pakaian yang lazim dikenakan oleh orang-orang yang mendalami tasawuf atau kaum sufi . Kain wol yang mereka pakai adalah kain wol kasar, bukan wol yang halus dan mahal seperti sekarang ini. Pakaian wol ini dulu sebagai simbol kesederhanaan dan kesahajaan. Dengan pakaian ini kaum sufi mengidentikan diri sebagai kelompok yang bergaya hidup sederhana.

Secara terminologis, definisi tasawuf bermacam-macam. Setiap ulama dan imam sufi mengungkapkan definisi tasawuf berbeda-beda, sesuai dengan pengalaman batin yang mereka alami masing-masing. Syaikh Markhuf Al-Kurkhi mengungkapkan bahwa tasawuf mengambil hakikat dan putus asa terhadap apa yang ada ditangan makhluk. Sedangkan imam besar kaum sufi, yaitu imam Junaid Al-Baghdâdi mengatakan bahwa tasawuf adalah keyakinan bahwa engkau bersama Allah SWT tanpa penghubung dengan siapapun ${ }^{93}$ Dan kata tasawuf dapat memiliki beberapa kemungkinan tentang asal usulnya diantaranya adalah berasal dari kata ibnu sauf yang sudah dikenal sebelum Islam datang sebagai gelar seorang anak Arab yang saleh, yang selalu mengasingkan diri dekat Ka'bah guna mendekatkan diri kepada Tuhannya ia bernama Ghaus bin Murr. Atau yang yang lain adalah kata tasawuf diambil dari perkataan suffah yang dipergunakan

\footnotetext{
${ }_{92}$ Ahmad Ibn Muhammad Banâni, Mawqifu Al-Imâm Ibn Taymiyyah Min AlTashawwuf wa Al-Shūfiyyah, Riyadh : Dâr Al-Ilm, 1406 H, Hlm. 67-68.

93

2016, hlm 27-28

Majalah Cahaya Nabawi: Memahami Tasawuf, Edisi : 155, Desember
} 
untuk nama surat ijazah untuk orang naik haji. Bisa juga dimungkinkan berasal dari kata sophia yang berarti hikmah atau filsafat. ${ }^{94}$

Untuk lebih jauh Zaki menawarkan kembali sebuat istilah dengan tasawuf Islami, "adalah mempunyai pengertian membersihkan diri (takhali) dari sesuatu yang hina, dan menghiasinya dengan sesuatu yang baik untuk mencapai tingkat yang lebih dekat dengan Allah atau sampai kepada maqam yang tinggi." "95 Dan untuk inilah Al-Ghazâlî menarik pengertian tasawuf dari hadis Rasulullah SAW. mengenai agama apa itu agama tentang Islam, Iman dan Ihsan untuk memberikan kesan tentang tasawuf meruupakan ajaran Islam yang bersumber dari sifat Ihsan jadi menurut Al-Ghazâlî tasawuf merupakan rukun dalam agama. ${ }^{96}$

Pada akhir kesimpulan dalam perbedaan pendapat ini, tidak ada satu pendapat manapun yang dianggap lebih tepat dari yang lain, maka setiap bagian kata akan digunakan untuk mewakili eksistensi dari tasawuf. Jika tasawuf yang dimaksud adalah akhlak maka akan mengambil definisi Al-Shafä', jika tasawuf adalah zuhud maka akan diambil pengertian $A l-S h \bar{u} f$, begitu selanjutnya, dimana setiap bagian dari kata tasawuf dapat digunakan untuk menunjukan hakikat yang hendak dibicarakan.

\section{Sejarah Dan Perkembangan Tasawuf}

Begitu juga ketika bicara tentang sejarah munculnya tasawuf, sampai kepada pelembagaannya, terdapat perbedaan pencatatan dan pendapat-pendapat tentang sebab munculnya. Dalam muqaddimahnya Ibnu Khaldun mengatakan "Ilmu tasawwuf adalah salah satu diantara ilmu-ilmu syariat yang baru dalam Islam. Asal mulanya ialah amal perbuatan ulama salaf dari para sahabat, tabiin dan orang-orang sesudah mereka. Dasar tasawuf adalah ialah tekun beribadah memutuskan jalan selain jalan menuju Allah berpaling dari kemegahan dan kemewahan terhadap dunia, melepakan diri dari apa yang

\footnotetext{
94 Safrudin Aziz, Pendidikan Seks Berbasis Terapi Sufistik Bagi LGBT, Penerbit: ernest, 2017, Kendal, hlm. 147

${ }^{95}$ Muhammad Zaki Ibrahim, Tasawuf Hitam Putih, Solo: Penerbit Tiga Serangkai, 2006, cet. 2, Hlm. 3

96 Himawijaya, Mengenal Al-Ghazali For Teens: Keraguan Adalah Keyakinan, Bandung: Dar! Mizan, 2004, hlm. 55-56
} 
diinginakan oleh mayoritas manusia berupa kelezatan harta dan pangkat, serta mengasingkan diri dari makhluk dan berkhalwat untuk beribadah, yang demikian ini sangat umum dilakukan oleh para sahabat dan ulama salaf. Lalu ketika manusia mulai condong dan terlena dengan urusan duniawi pada abad kedua dan setelahnya, nama sufi mulai dikhususkan bagi orang-orang yang tekun beribadah saja."

Muhammad shadiq Al-Ghumari mengatakan bahwa pendapat Ibnu Khaldun mengenai sejarah munculnya tasawuf ini diperkuat oleh pendapat yang disampaikan oleh Al-Kindi dalam kita Wulât Mishr dalam pembahasan yang terjadi pada tahun 200 Hijriah. Pada waktu itu kota Iskandariyah muncul sekelompok orang yang bernama sufi, yang menyeru kepada kebaikan.

Dalam pendapat Al-Mas'udi dalam kitab Murūd Al-Dzahab, AlMas'udi meriwayatkan dari Yahya ibn Aktsam bahhwa pada suatu hari Khalifah Makmun sedang duduk di Istana, ketika Ali ibn Shaleh masuk sambil berkata, "Wahai amirul mukminin ada seorang laki-laki diluar. Dia memakai pakaian putih yang kasar dan memohon agar bertemu denganmu untuk mendiskusikan sesuatu. Dan setahuku dia dari kalangan sufi."

Haji Khalifah menyebutkan bahwa orang yang pertama kali dinamakan dengan sufi adalah Abu Hasyim Al-Shūfi yang wafat pada tahun $150 \mathrm{H}$, "Ketahuilah bahwa kaum muslimin sesudah Rasulullah tidak menamakan orang-orang yang paling utama diantara mereka dengan nama selain 'sahabat', sebab ketika itu tidak ada nama yang paling utama diantara mereka dari nama 'sahabat'. Setelah era sahabat, manusia berselisih dan tingkatan mereka semakin bervariasi. Orang yang tekun menjalankan agama disebut zāhid (ahli zuhud) atau 'ābid (ahli ibadah).

Kemudian muncullah bid'ah, dan setiap kelompok mengklaim bahwa didalam kelompok mereka ada orang yang berlaku zuhud. Setelah itu ahli zuhud dari kalangan ahlussunnah yang senantiasa memelihara hubungan mereka dengan Allah dengan menjaga hati mereka dari kelalaian, menggunakan istilah tasawuf secara khusus. Istilah ini telah populer dikalangan mereka sebelum abad kedua hijriah"97

97 Abdul Qodir Isa, Hakikat Tasawuf, Jakarta: Qisthi Press, 2005, Hlm. 12-13. 
Setelah itu perkembangan tasawuf semakin berkembang, sehingga memunculkan dua cabang tasawuf yaitu tasawuf Tarikati yang kemudian dikenal dengan nama Tasawuf Ahli Sunnah, dan Tasawuf Falsafi. Dan ajaran Tasawuf yang dicerna dengan baik oleh seluruh umat Islam di Dunia adalah Tasawuf Tarikati. Menurut Kamil Mushtafa Al-Syibi bahwa tokoh pertama yang memperkenalkan sistem tarikat dalam ajaran tasawuf adalah Abdul Qadir Al-Jailani di Baghdad yang ajarannya menyebar luas di Al-Jazāir, Ghana, dan Indonesia.

Dan corak tasawuf falsafi mulai menemukan momentumnya pada abad ke-3 dan ke-4 dengan munculnya al-Husain Ibn Manshūr AlHallaj dengan doktrin hululnya. Sehingga pada abad ke-5 H Imam AlGhazali tampil untuk menentang jenis-jenis tasawuf yang dianggap tidak sesuai dengan Al-Quran dan Sunnah dalam upaya untuk mengembalikan tasawuf status semula sebagai jalan zuhud, pendidikan jiwa dan dan pembentukan moral. Dan sejak kemunculan Imam AlGhazali Tasawuf semakin menyebar di dunia Islam. Akan tetapi bukan berarti orieantasi tasawuf falsafi pada tataran ide wahdatul wujūd berhenti, pada abad ke-6 H Syaikh Al-Akbar Ibn Al-'Arabi dan diikuti oleh beberapa tokoh tasawuf lain, menggagas ide aliran wahdat alwujud yang mengarahkan tasawuf pada kebersatuan terhadap Allah. Kemudian dalam wacana polemik dua kutub tasawuf tersebut muncullah seorang tokoh tasawuf yang terinspirasi dengan konsep tasawuf Imam Al-Ghazali yaitu Syaikh Abdul Qadir, dan Syaikh Ahmad Al-Rifā'i. Dan kemudian setelahnya masih pada abad ke-6 muncul tokoh tasawuf Syaikh Abu Al-Hasan Al-Syadzili yang mencoba untuk menengahi tasawuf Al-Ghazali dengan tasawuf falsafi. ${ }^{98}$

Ada paparan menarik yang diungkapkan oleh Hitti, tentang perkembangan ajaran tasawuf, "Pada mulanya tasawuf berkembang sebagai gaya hidup asketis, lebih khusus lagi kontemplatif, sebagaimana dipraktekan oleh para pendeta kristen.

Pada abad ke-2 dan seterusnya tasawuf berkembang menjadi gerakan sinkretis menyerap berbagai elemen dari Kristen, NeoPlatonik, Gnostisisme, dan Budhisme, serta berkembang melalui tahaptahap mistis, teosofis, dan panteistis. Pakaian wol dipakai diadopsi sebagai pakaian khas mereka, meniru pendeta kristen yang juga

${ }^{98}$ Muhammad Solikhin, Menyatu Diri Dengan Ilahi, Yogyakarta: Narasi, 2010, Hlm. 25-37. 
menjadi model penerapan gaya hidup selibat yang tidak pernah diterapkan sebelumnya oleh kalangan muslim ortodoks.

Praktik meditasi ditempat yang sunyi, dan kebiasaan berjaga malam atau yang semisalnya menunjukkan adanya pengaruh monastik suriah, kelompok sufi yang berkembang pada abad ke-13 M mengembangkan konsep relasi antara guru dengan muridnya. Konsep relasi ini erat hubungannya dengan model relasi antara pendeta dan murid pemula dalam tradisi kristen, juga serupa dengan aliran-aliran monastik lainnya, meskipun ada hadis kondang yang berbunyi, "tidak ada kependetaan (rahbaniyyah) dalam Islam".

Ritual keagamaan dalam tareqat yang disebut dzikr, merupakan satu-satunya ritual dalam Islam yang rumit dan berbeda dengan praktrik litani dalam kristen. Tradisi-tradisi eskatologis sufi dengan ajaran antikristusnya menganjurkan bahwa setiap tarekat mesti mendapatkan pengikut-pengikut baru diantara orang-orang yang baru masuk Islam.

Fenomena semacam itu merupakan gambaran dari bentukbentuk monoteisme yang lebih tua. Istilah sufi pertama kali dalam literatur arab pada pertengahan abad ke-9 $\mathrm{M}$ yang merujuk pada golongan asketis tertentu. Orang pertama yang mendapatkan julukan sufi adalah seorang ahli klenik ternama Jābir Ibn Hayyān (w. 776 M) yang mengembangkan ajaran asketiknya sendiri.

Sufi yang sezaman dengannya, Ibrahim Ibn Adham (w. 776 M) dari Balkh bisa dijadikan sebagai model gerakan asketisme diam yang muncul paling awal. Berkat rangsangan dari ajaran Kristen dan gagasan Yunani, asketisme Islam berkembang menjadi ajaran mistik mulai abad ke-2 $\mathrm{H}$.

Maka setelah itu tasawuf dianggap sebagai manajemen emosi untuk memurnikan jiwa manusia, sehingga asketisme memungkinkan manusia untuk mencintai, mengetahui dan bersatu dengan tuhan. Tetapi sufi pertama dari mazhab mistik, bukan dari mazhab asketik adalah Ma'rūf Al-Karkhī dari Baghdad yang meninggal pada tahun $815 \mathrm{M}$. Pada awalnya ia beragam Kristen, atau mungkin penganut kaum Saba. Setelah menjadi orang Sufi, ia diyakini sebagai orang yang terserap dalam mabuk Tuhan, dan dianggap sebagai orang suci atau wali." $" 99$

${ }^{99}$ Philip Khuri Hitti, History Of The Arabs, Jakarta: Serambi, 2006, Terjemahan, Hlm. 547-548. 
Kemudian ditambahkan menurut Ibn Taymiyyah bahwa kata sufiyyah tidak dikenal pada abad ke-3 $\mathrm{H}$, dan ia mulai dikenal setelahnya lewat ucapan-ucapan manusia setelahnya seperti Imam Ahmad Ibn Hambal, Abu Sulaiman Al-Dārāniy dan selain mereka. Dan mereka tidak menetapkan dari mana sebenarnya asal kata tasawuf atau sufi, namun mereka hanya menyebutkan dibeberapa ungkapan mereka tentang nama Tasawuf. Dan menurut Ibn Taymiyyah bisa jadi penamaan kelompok ini dengan nama sufi dikaitkan dengan sebuah hadis yang diriwayatkan oleh Muslim dalam shahihnya;

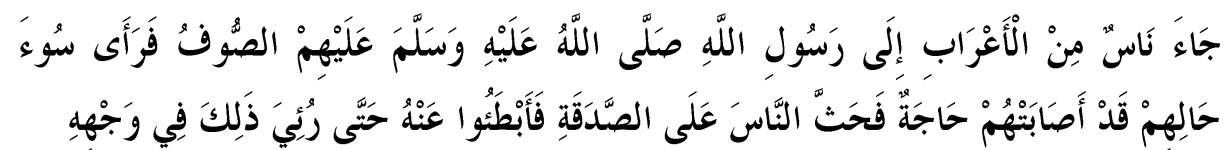

"Pada suatu ketika, beberapa orang Arab badui datang menemui Rasulullah shallallahu 'alaihi wasallam dengan mengenakan pakaian dari bulu domba (wol). Lalu Rasulullah memperhatikan kondisi mereka yang menyedihkan. Selain itu, mereka pun sangat membutuhkan pertolongan. Akhirnya, Rasulullah shallallahu 'alaihi wasallam menganjurkan para sahabat untuk memberikan sedekahnya kepada mereka. Tetapi sayangnya, para sahabat sangat lamban untuk melaksanakan anjuran Rasulullah itu, hingga kekecewaan terlihat pada wajah beliau." (H.R. Muslim) ${ }^{\mathbf{1 0 0}}$

Dalam hadis ini diketahui bahwa memakai pakai wol merupakan tanda dari kemiskinan, kelemahan dan kesempitan, dalam hal ini orang-orang yang memakai pakaian wol sudah ada pada masa Nabi SAW. Kemudian dalam hadis riwayat Imam Ahmad juga diutarakan tentang orang-orang yang menemui Nabi SAW. dalam keadaan miskin dimana mereka memakai pakai dari wol;

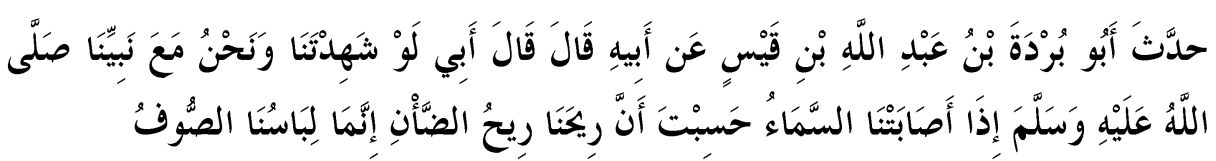

"Telah menceritakan Abu Burdah bin Abdullah bin Qais dari Bapaknya berkata; Bapakku berkata; "Kalaulah kamu tahu apa yang ada pada kami sewaktu kami bersama Nabi Shallallahu'alaihiwasallam ketika kami tengah tertimpa hujan lebat, tentulah kalian mengira bau kami

${ }^{100}$ Muslim Ibn Hajjaj Al-Qusairiy An-Naisabūri, Shah̄̄h Muslim, Riyādh: Bait AlAfkar, 1419 H, Bab Zakat, No. 4830 
adalah (bau) domba sedang kami memakai kain wol." (H.R. Ahmad) ${ }^{101}$

Pada masa itu pakaian terbaik adalah pakaian yang terbuat dari kapas, maka orang-orang yang miskin tidak akan sanggup membeli pakaian yang terbuat dari kapas sehingga mereka memakai pakaian dari kain wol. Kemudian dalam hadis yang lain yang diriwayatkan dari Imam Muslim dan Ahmad;

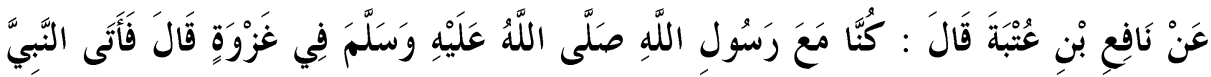

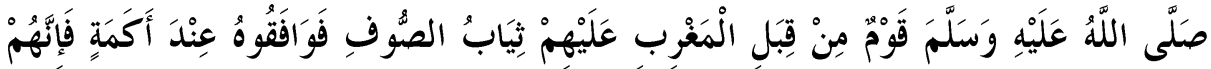

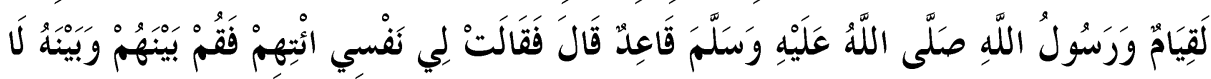

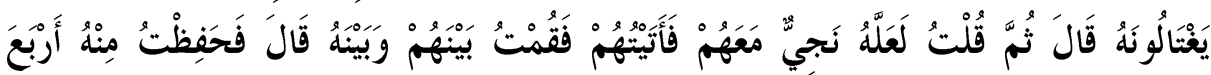

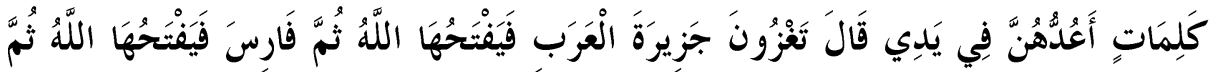

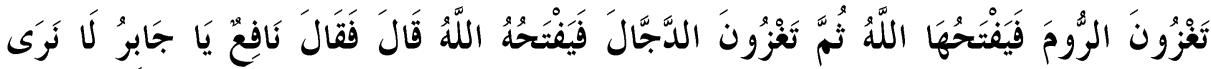

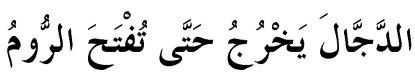

Dari Nafi' bin Utbah berkata: Kami bersama Rasulullah Shallallahu 'alaihi wa Salam dalam suatu peperangan. Ia berkata: Suatu kaum mendatangi nabi Shallallahu 'alaihi wa Salam dari maghrib, mereka mengenakan baju wool, mereka menemui beliau didekat suatu bukit. Mereka berdiri sementara Rasulullah Shallallahu 'alaihi wa Salam duduk. Ia (Nafi') berkata: Hatiku berkata: Datangilah mereka dan berdirilah diantara mereka dan Rasulullah Shallallahu 'alaihi wa Salam agar mereka tidak menyerang beliau lalu aku berkata: Mungkin beliau berbicara lirih dengan mereka. Aku mendatangi mereka lalu aku berdiri diantara mereka dan beliau. Aku menghafal empat kalimat dari beliau, aku menghitungnya dengan tanganku. Beliau bersabda: "Kalian akan memerangi jazirah arab lalu Allah menaklukkannya, setelah itu Persia lalu Allah menaklukkannya, kemudian kalian memerangi Romawi lalu Allah menaklukkannya, selanjutnya kalian memerangi Dajjal lalu Allah menaklukkannya." Kemudian Nafi' berkata: Hai Jabir, kami tidak berpendapat Dajjal muncul hingga Romawi ditaklukkan. (H.R. Muslim) ${ }^{102}$

${ }^{102}$ Muslim Ibn Hajjaj Al-Qusairiy An-Naisabūri, Shahīh Muslim, Riyādh: Bait AlAfkar, 1419 H, Bab Fitnah Dan Tanda Kiamat, No. 5161 
Inilah hadis-hadis yang menerangkan tentang pakaian wol yang sudah dipakai oleh manusia-manusia yang hidup pada masa Nabi SAW. dimana mereka dilekatkan dengan kemiskinan dan kelemahan. Dari hadis-hadis ini menerangkan bahwa kebayakan masyarakat arab badui yang tinggal diperkampungan-perkampungan yang jauh dari pusat kota mereka memakai pakaian yang terbuat dari kain wol yang berasal dari bulu-bulu domba dan mereka memakai pakaian tersebut baik dalam keadaan panas maupun dalam keadaan dingin. Namun setelah itu, orang-orang yang memakai pakaian wol adalah orang-orang yang hendak menunjukan sifat zuhud, tawādu', menjauhi dari kelezatan dunia. Maka dengan ini Imam Ahmad Ibn Hambal, juga Ibn Taymiyyah dan para ulama hadis lebih cendrung mengartikan sufi dengan arti shūf (pakaian wol). Dan ada hadis lain yang menguatkan pendapat mereka bahwa pakaian wol merupakan pakaian yang lekat dengan kezuhudan dan ketakwaa, sebuah hadis dari Tirmidzi;

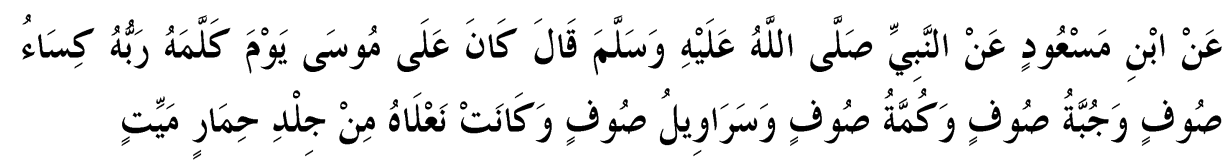

Dari Ibnu Mas'ud dari Nabi shallallahu 'alaihi wasallam, beliau bersabda: "Pada hari ketika Rabbnya berbicara dengannya, Musa mengenakan kain wol, jubah wol, peci wol, dan celana panjang dari wol. Sementara kedua sandalnya terbuat dari kulit himar yang telah mati."

Ibnu Taymiyyah juga berbicara hakikat dari sufi atau tasawuf dengan menukil perkataan dari para ulama salaf. Muhammad Ibn Sirin menceritakan "telah sampai sebuah kaum yang melebih utamakan dalam memakai pakaian wol, dikatakan bahwa mereka lebih memilih memakai pakaian yang berbahan dari wol, dan mereka mengakui bahwa perbuatan mereka ini mengikuti para pengikut agama Masehi. Dan Nabi SAW telah memberikan petunjuk kepada kita dengan memakai pakaian yang berasal dari kapas." Pada masa Hasan Al-Bashri juga pernah mendapatkan orang-orang zuhud yang hidup saat memakai pakaian dengan berbahan dari wol, ketika melihat tersebut Ia mengatakan "Petunjuk Nabi kita lebih kita sukai, dan Nabi kita tidak pernah mensyari'atkan dengan pakaian ini dan juga tidak pernah memerintahkan agar kita memakai pakaian ini, kecuali hal ini merupakan perkara yang baru” Kemudian Malik Ibn Anas Al- 'Âmiriy 
telah menuliskan bahwa Hasan Al-Bashri tidak menyukai memakai pakai wol untuk menunjukan dirinya sebagai seorang yang zuhud. ${ }^{103}$

Adapun kapan munculnya nama sufi dan penyebutannya, diceritakana dalam sebuah majelis seorang tokoh sufi terkenal di Baghdad Muhammad Ibn Ibrahim Abu Hamzah Al-Shūfi, terdapat Imam Ahmad Ibn Hanbal dalam majelis tersebut dan bertanya kepada Muhammad Ibrahim dengan perkataan : "ما تقول : فيها يا صوفي" (apa jawabannya wahai sufi). Menurut Ibn Taymiyyah, Abu Hamzah (w. $289 \mathrm{H}$ ) adalah orang yang pertama kali yang berbicara tentang madzhab sufi, dintara ajarannya adalah, shafā' al-dzikr (ketenangan zikir), jam 'u al-himmah (mengumpulkan semangat), al-mahabbah (cinta), dan alsyauq (kerinduan), dan sebelumnya tidak ada yang berbicara tentang masalah-masalah ini. ${ }^{104}$

Kemudian Ihsan Ilahi Zhahir menyebutkan bahwa munculnya kalimat tasawuf diperselisihkan kapan mulai disebut, seperti Ibnu Jauzi dan Ibn Khaldun juga menyebutkan bahwa hingga abad ke-3 nama ini belum menjadi nama yang dikenal oleh kaum Muslimin. Sirāj Al-Thūsi $($ w.378 H) tokoh tasawuf mengatakan perihal kemunculan kata tasawuf;

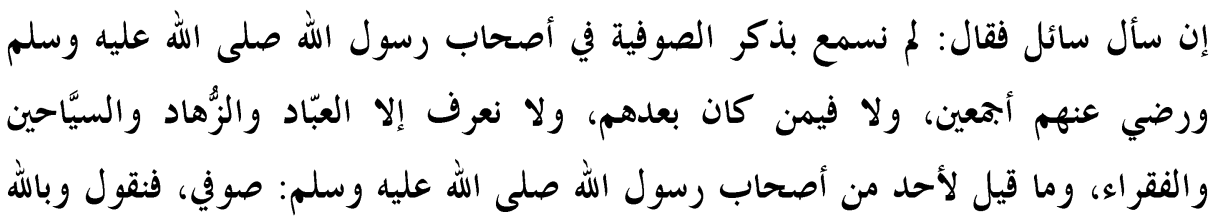

Seseorang pernah bertanya (tentang tasawuf) : Kami belum pernah mendengar penyebutkan sufiyyah dari para sahabat Rasulullah SAW. dan juga tidak setelahnya, dan kami tidak mengetahui kecuali adanya ahli ibadah, ahli zuhud, orang-orang yang berpergian, orang-orang miskin, dan tidaklah mereka dikatatan oleh para sahabat Rasulullah SAW. dengan dengan sufi, dan kami katakan wa bi Allah Al-Tawfíq .

103 AbdAl-Qodir Ibn HabibAllah Al-Sindî, Al-Tashawwuf Fi Mîzan Al-Bahts Wa Al-Tahqî̀ Wa Al-Râd 'Alâ Ibn Al-'Arabiy Al-Shūfiy Fî̀ Dhaw'i Al-Kitâb Wa AlSunnah, Madinah : Maktab Ibn Al-Qayyim, 1410 H hlm. 31-40.

${ }^{104}$ AbdAl-Qodir Ibn HabibAllah Al-Sindî, Al-Tashawwuf Fi Mîzan Al-Bahts Wa Al-Tahqîq Wa Al-Râd 'Alâ Ibn Al-'Arabiy Al-Shūfiy Fî̀ Dhaw'i Al-Kitâb Wa AlSunnah, , Madinah : Maktab Ibn Al-Qayyim, 1410 H, Hlm.41-45. 
Sufyan Al-Tsauri menyebutkan bahwa nama Sufi sudah dikenal bahkan jauh sebelum datangnya Islam.

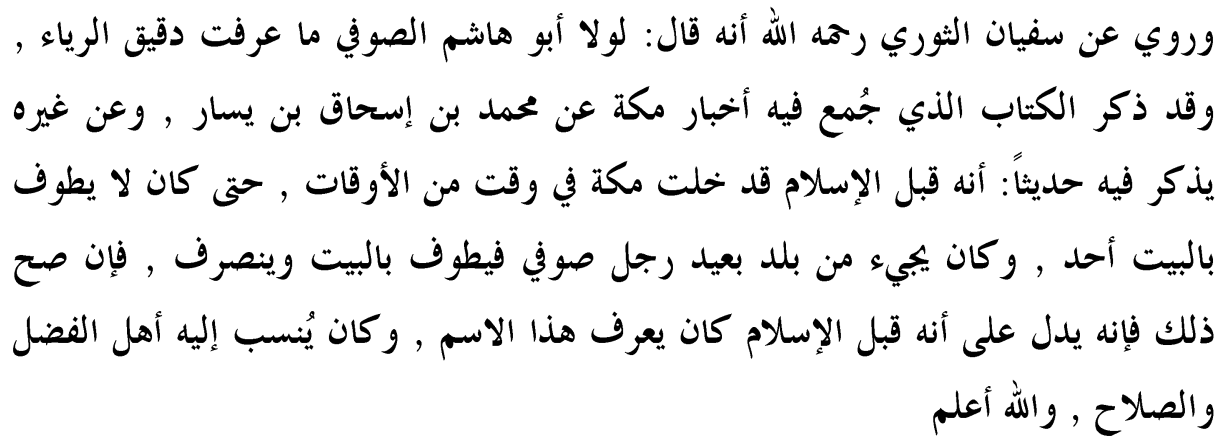

Diriwayatkan dari Sufyān Al-Tsauriy bahwa ia berkata : Kalau bukan karena Abu Hāsyim Al-Shūfi, maka aku tidak akan tahu tentang kedalaman riya, dan telah disebutkan dalam buku yang mengumpulkan didalamnya informasi tentang Makah dari Muhammad Ibn Ishāq Ibn Yassār dan dari selainnya menyebutkan sebuah peristiwa : 'Sebelum Islam telah berlalu waktu demi waktu, sampai tidak ada manusia yang tidak thawaf, setelah itu datanglah dari negeri yang jauh seorang sufi yang melakukan thawaf di Kabah dan berlalulah ia, maka jika itu benar maka hal tersebut menjadi tanda bahwa sebelum Islam nama Sufi sudah dikenal, dan nama tersebutkan dihubungkan kepada ahli keutamaan dan dan perbaikan, wa Allah 'Alam ${ }^{105}$

Dalam penjelasan-penjelasan sebelumnya jelas tidak ada yang bersepakat tentang kapan munculnya tasawuf dan bentuknya. Namun jika kita ringkas perbedaan ini dapat disimpulkan, sufi sudah ada sebelum nabi diutus sebagai Nabi akhir zaman, kemudian hakikat sufi pada awalnya tidak ada karena, seseorang yang dipanggil sufi hanyalah orang salih yang beribadah di kabah dan mengurusi kabah saat itu, pada tahap selanjutnya adalah tidak ada yang dapat meyakinkan kapan tasawuf mulai dipelajar oleh manusia, kecuali setelah abad ke-3 diwilayah Baghdad, dan tokoh pelopornya juga tidak bisa dipastikan siapa, kecuali setelah kemuncul tarikat-tarikat sufi maka pemiliki ajaran tasawuf dilekatkan kepada pemilik tarikat-tarikat tersebut.

105 Ihsan Ilâhi Dzâhir, Al-Tashawwuf Al-Mansya`Wa Al-Mashâdir, 1406 H, Pakistan, Idârah Tarjaman Al-Sunnah, Hlm. 41. 


\section{Konsep Al-Quran Tentang Zuhud}

Zuhud secara bahasa adalah zahada fihi, zahada 'anhu, zuhdan wa zahdan, yaitu berpaling darinya dan meninggalkannya karena menganggap hina, atau menjauhinya karena dosa, dikatakan barang itu zāhid maksudnya barang itu sedikit dan tidak bernilai. ${ }^{106}$

Zuhud merupakan ungkapan berpalingnya seseorang dari keinginan terhadap sesuatu kepada sesuatu yang lebih baik dari sebelumnya. Meninggalkan indahnya Dunia menuju kepada indahnya Akhirat. Mengosongkan keinginan dalam hati dari segala sesuatu yang tidak bisa dicapai dengan tangannya. Dan ia mengetahui bahwa dunia adalah hanyalah bayang-bayang yang akan sirna, dan angan yang akan berlalu, sebagaimana yang Allah SWT. firmankan dalam QS. Al-Hadīd [57]: 20 :

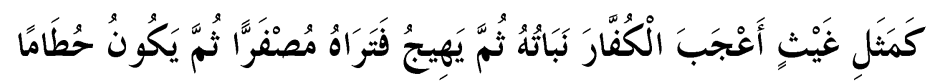

"Seperti hujan yang tanam-tanamannya mengagumkan para petani; kemudian tanaman itu menjadi kering dan kamu lihat warnanya kuning kemudian menjadi hancur." ${ }^{107}$ Ibn Katsir menjelaska ghaits adalah hujan yang turun turun setelah para manusia berputus asa dengan datangnya hujan. Kemudian kekaguman para petani terhadap tanamannya seperti kekaguman orang-orang kafir terhadap dunianya, sehingga mereka bersemangat untuk mendapatkannya dan cendrung terhadapnya. ${ }^{108}$

Kemudian Al-Hasan juga menjelaskan tentang makna zuhud dengan ungkapan;

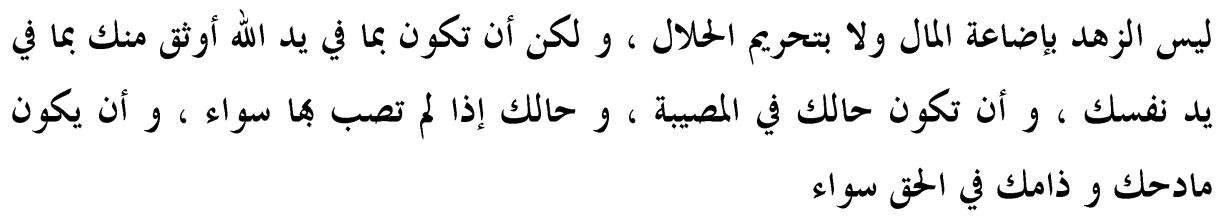

"Seorang ahli zuhud itu bukanlah mengabaikan harta atau mengharmkan yang halal, akan tetapi engkau menjadikan sesuatu yang

106 Abu Fida' Abu Rafi', Menjadi Kaya Dengan Menikah, Jakarta: Penerbit Replubika, 2007, cet. 3, Hlm. 28.

107 Sa'̄̄d 'Abd Al-'Azhīm, Al-Zuhd : Izhad F̄̄ Al-Dunya Yuhbibuka Al-Nās, Iskandariyah: Dār Al-Īmān, 2004 M, hlm. 3-4.

${ }^{108}$ Muhammad Karīm, Ar-Rājih, Mukhtashar Tafsīr Ibn Katsīr Tafsìr Al-Qur'ān Al- 'Azhīm, Beirut: Dār Al-Ma'rifah, 1420, Jilid 2, Hlm. 595. 
berada dalam genggaman Allah SWT. lebih pasti bagimu dari sesuatu yang ada genggamanmu, dan menjadikan keadaanmu dalam musibah ataupun tidak itu sama, dan menjadikan pujian dan celaan kepadamu dalam kebenaran adalah sama."

Menurutnya Ibn Taymiyyah, zuhud terhadap sesuatu adalah menghilangkan keinginan dan kebencian, maka bukanlah zuhud jika masih memiliki keinginan terhadap sesuatu dan tidak membenci terhadap sesuatu, maka jika seseorang menghilangkan hasrat dan keinginan terhadap sesuatu maka itu adalah zuhud. Kemudian Ibn Taymiyyah kembali melanjutkan tentang hakikat zuhud;

$$
\text { الزهد المشروع ترك ما لا ينفع في الدار الآخرة وثقة القلب بما عند الله }
$$

Zuhud yang disyariatkan adalah meninggalkan segala sesuatu yang tidak bermanfaat bagi Akhirat, dan percaya dalam hati dengan segala segala sesuatu yang ada pada sisi Allah SWT. ${ }^{109}$

Maka tidak salah jika seorang zuhud adalah seorang yang fakir lagi miskin, tetapi terkadang seorang ahli zuhud bisa dari orang kaya dan terpandang. Mengenai pembicaraan al-zuhd al-mahmūd (zuhud terpuji) dan al-zuhd al-madzmūm (zuhud tercela), maka Nabi SAW. adalah ahli zuhud diantara manusia lainnya, tapi Ia SAW. tidak menolak materi dan tidak memaksa agar materi itu hilang, dia memakai pakaian yang mudah yang merupakan jenis-jenis pakaian baik dari bahan pakaian yang terbuat dari kapas ataupun wol, dan Nabi SAW. menolak untuk mengkhusus dalam pakaian tertentu terhadap dirinya, atau dengan alasan zuhud Nabi SAW. memutuskan diri terhadap manusia lainnya. Sampai Nabi SAW. pernah berbicara dengan suara yang tinggi kepada para sahabatnya, dengan ucapan :

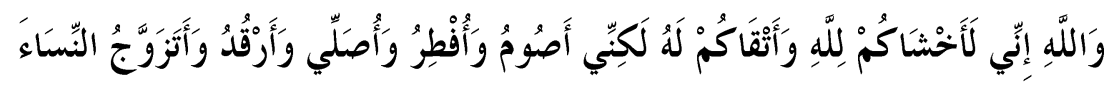

"Demi Allah, adalah orang yang paling takut kepada Allah di antara kalian, dan juga paling bertakwa. Aku berpuasa dan juga berbuka, aku shalat dan juga tidur serta menikahi wanita." (H.R. Al-Bukhari, No. 4675) ${ }^{110}$

Maka jika arti zuhud adalah memutuskan dirinya terhadap dunia, dia tinggalkan hartanya, keluarganya, anak-anaknya, maka ini

${ }^{109}$ Fathi Majdi Al-Sayyid, Al-Zuhd : Li Al-Imām Abi 'Abd Allah Al-Qurthubī, Mesir: Maktabah Al-Shahābah, 1408 H. Hlm. 15. 
bukan zuhud yang dimaksud, dan Islam berlepas diri atasnya. ${ }^{111}$ Imam Al-Ghazali menyebutkan hakikat dari zuhud, dimana zuhud adalah bentuk keseimbangan antara dunia dan akhirat, antara syahwat dan pengendalian syahwat;

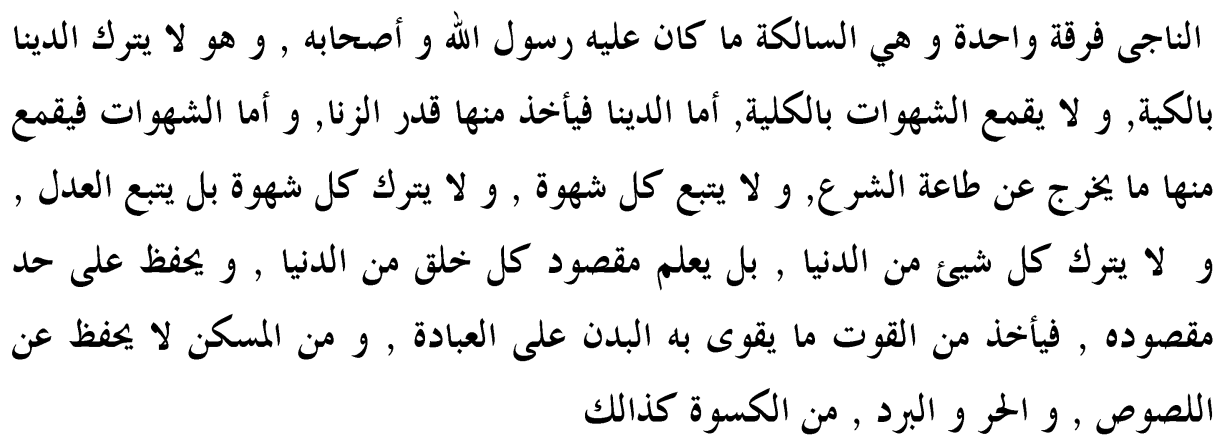

Yang selamat itu hanya satu kelompok, yaitu kelompok yang berjalan diatas petunjuk Rasulullah SAW. dan sahabatnya, ia tidak meninggalkan dunia seluruhnya dan tidak memadamakan syahwat seluruhnya, adapun dunia itu ia akan mengambilnya sesuai dengan kadarnya, adapun berbagai syahwat maka ia akan menekan darinya syahwa yang akan mengeluarkan dari ketaatan terhadap syariat, dia tidak mengikuti mengikuti syahwat, dan ia tidak juga meninggalkan semua syahwat namun ia akan mengikutinya dengan adil, ia tidak meninggalkan segala sesuatu dari Dunia, namun ia mengetahui tujuan dari diciptakannya dunia ini, dan ia menjaga terhadap lingkup tujuanya, ia mengambil dari kekuatan-kekuatan yang ada pada tubuhnya untuk beribadah dan dari tempat tinggalnya yang tidak terjaga dari penjaganya, dari panas dan dingin, begitu juga dari pakaiannya. ${ }^{112}$

Untuk ayat-ayat zuhud tidak ada terma khusus yang memuat kata zuhud, namun ada ayat-ayat yang dapat dikaitkan dengan amal zuhud diantaranya adalah berikut ini :

${ }^{111}$ Fathi Majdi Al-Sayyid, Al-Zuhd Li Al-Imām Abi 'Abd Allah Al-Qurthubī, , Mesir: Maktabah Al-Shahābah, 1408 H. Hlm. 15.

${ }^{112}$ Fathi Majdi Al-Sayyid, Al-Zuhd : Li Al-Imām Abi 'Abd Allah Al-Qurthubī, Mesir: Maktabah Al-Shahābah, 1408 H. , Hlm. 19. 


\section{a. Q.S. Al-Qashāsh [28]: 77}

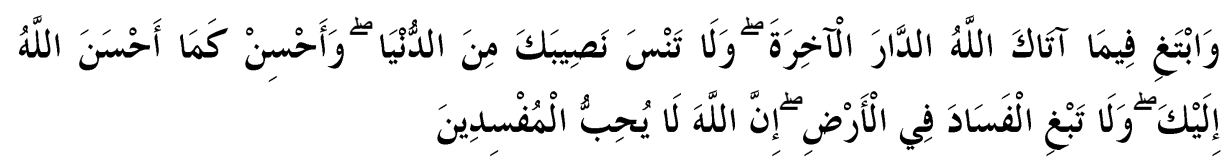

"Dan carilah pada apa yang telah dianugerahkan Allah kepadamu (kebahagiaan) negeri akhirat, dan janganlah kamu melupakan bahagianmu dari (kenikmatan) duniawi dan berbuat baiklah (kepada orang lain) sebagaimana Allah telah berbuat baik, kepadamu, dan janganlah kamu berbuat kerusakan di (muka) bumi. Sesungguhnya Allah tidak menyukai orang-orang yang berbuat kerusakan."

Ibn Katsir menafsirkan pada kalimat ابتَّْ dengan arti mempergunakan, dan kata pada kalimat selanjutnya ia katakan dalam tafsirnya :

$$
\text { بأنواع التقبمل ما وهبك الله من هذا المال الجزيل والنعمة الطائلة في طاعة ربك والتقرب إليه }
$$

"Pergunakanlah segala pemberian Allah SWT. berupa harta yang banyak, kenikmatan yang langgeng, untuk taat kepada Rabbmu dan mendekatkan diri kepada kepada Allah SWT. dengan berbagai bentuk pendekatan yang akan menghasilkan balasan di Dunia dan Akhirat."

Dalam potongan ayat ini anjuran agar kita berperilaku zuhud dalam keadaan kita memiliki harta, karena itu zuhud tidak lantas dia fakir dan miskin, namun tantangan zuhud adalah saat seseorang memiliki harta namun ia mampu menjadikannya semakin dekat dengan Allah SWT. dan ia mampu mendapatkan kebaikan pada dua tempat yaitu dunia dan akhirat. Kemudian pada potongan ayat berikutnya Allah SWT berfirman agar kita tidak melupakan bahagian kita pada dunia ini, mengenai lanjutan ayat ini Ibn Katsir menyatakan;

$$
\begin{aligned}
& \text { أي مما أباح الله فيها من المآكل والمشارب والملابس والمساكن والمناكح فإن لربك عليك حقا } \\
& \text { ولنفسك عليك حقا ولأهلك عليك حقا ولزورك عليك حقا فآت كل ذي حق حقه }
\end{aligned}
$$

"(jangan lupakan bagianmu dari Dunia) adalah dari segala sesuatu yang Allah SWT. bolehkan didalamnya, seperti makan, minum, berpakain, bertempat tinggal, menikah, dan sesungguhnya Rabbmu memiliki hak atasmu dan dirimu memiliki hak atas dirimu, dan keluargamu memiliki hak atasmu, dan tetanggamu memiliki hak atasmu maka segala sesuatu memiliki hak atas haknya.". Pelajaran 
penting pada potongan ayat ini adalah, sifat zuhud tidak menjadikan seseorang harus meninggalkan dunianya, bahkan Allah SWT. berpesan agar seseorang tidak lupa dengan haknya, dan adalah sebuah keniscayaan bahwa setiap hak itu wajib untuk ditunaikan haknya, inilah arti dari kata nashībaka min al-dunyā', makan, menikah, tempat tinggal, istri, tetangga, yang tidak boleh dillupakan haknya bagi seseorang. ${ }^{113}$

Kemudian tafsir indah tentang ayat ini diungkapkan oleh Sayyid Quthub dalam kitab tafsirnya dengan memberikan sebuah gambaran tentang keharusan sikap umat Islam atas dunia, dengan mengatakan bahwa "Dalam perintah ini tercermin keseimbangan manhaj Ilahi yang lurus. Manhaj yang menggantungkan hati orang yang memiliki harta dengan akhirat, dan tidak melarangnya untuk mengambil sebagian harta dalam kehidupan dunia ini.

Bahkan, manhaj Ilahi ini mendorongnya untuk mencarinya dan menugaskannya untuk melakukan hal itu. Sehingga, ia tidak menjadi sosok yang membenci dunia, menyia-nyiakan dunia ini, dan melemahkan kehidupan ini. Dalam perintah ini tercermin keseimbangan manhaj Ilahi yang lurus. Manhaj yang menggantungkan hati orang yang memiliki harta dengan akhirat, dan tidak melarangnya untuk mengambil sebagian harta dalam kehidupan dunia ini. Bahkan, manhaj Ilahi ini mendorongnya untuk mencarinya dan menugaskannya untuk melakukan hal itu. Sehingga, ia tidak menjadi sosok yang membenci dunia, menyia-nyiakan dunia ini, dan melemahkan kehidupan ini. Karena Allah telah menciptakan kenikmatan dunia ini untuk dinikmati oleh manusia. Juga agar mereka berusaha di muka bumi untuk menyimpan dan menghasilkannya. Sehingga, tumbuhlah kehidupan ini dan terus berkembanglah ia, dan seterusnya terwujudlah kekhalifahan manusia di muka bumi ini. Tapi, dengan catatan bahwa arah mereka dalam menggunakan kenikmatan dunia ini adalah akhirat, sehingga mereka tak menyimpang di jalannya, dan tidak menyibukkan diri dengan kenikmatan dunia sementara melupakan tugastugasnya sebagai khalifah di muka bumi.

Dalam kondisi seperti ini, menikmati kenikmatan dunia menjadi suatu jenis kesyukuran bagi Allah Sang Pemberi nikmat, menerima anugerah-anugerahNya, dan menggunakan nikmat itu. Maka, ia

${ }^{113}$ Muhammad Karīm Ar-Rājih, Mukhtashar Tafsīr Ibn Katsīr Tafsìr Al-Qur'ān Al- 'Azhìm, Beirut: Dār Al-Ma'rifah, 1420, Jilid 2, Hlm. 237 
menjadi suatu bentuk ketaatan, yang Allah akan balas itu dengan kebaikan. Seperti itulah manhaj ini mewujudkan keseimbangan dan keserasian dalam kehidupan manusia, memberikannya kemampuan untuk meningkatkan ruhaninya secara terus-menerus melalui kehidup annya yang alami dan berkeseimbangan-dan manusia tak dilarang untuk merasakan kehidupan ini. Juga tidak menyianyiakan bangunan kehidupan Fitrah. Karena harta ini adalah pemberian dan anugerah dari Allah. Oleh karena itu, terimalah dengan berbuat baik padanya. Berbuat baik dalam menerima harta itu dan berbuat baik ketika menggunakannya Juga berbuat baik dengannya terhadap sesama manusia, berbuat baik dalam perasaan terhadap kenikmatan itu, dan berbuat baik dengan bersyukur. ${ }^{114}$

\section{b. Q.S. Al-Hadīd [57]: 23}

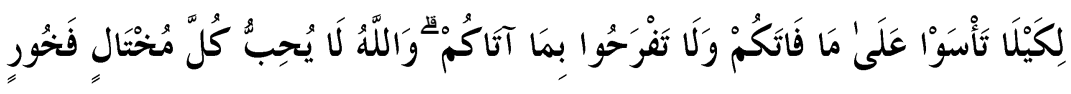

"(Kami jelaskan yang demikian itu) supaya kamu jangan berduka cita terhadap apa yang luput dari kamu, dan supaya kamu jangan terlalu gembira terhadap apa yang diberikan-Nya kepadamu. Dan Allah tidak menyukai setiap orang yang sombong lagi membanggakan diri."

Seorang ahli zuhud adalah seseorang yang tidak mudah untuk berduka cita terhadap kenikmatan yang luput darinya, dan tidak merasa sombong dengan kenikmata yang Allah SWT. karuniakan kepadanya. Ibn Katsīr menafsirkan arti dari kata آنَاكُم dengan arti أعطاكم yaitu pemberian kepada kalian. Selanjutnya Ibn Katsīr menjelaskan;

$$
\begin{aligned}
& \text { لا تفخروا على الناس بما أنعم الله به عليكم ، فإن ذلك ليس بسعيكم ولا كدكم ، وإنما هو }
\end{aligned}
$$

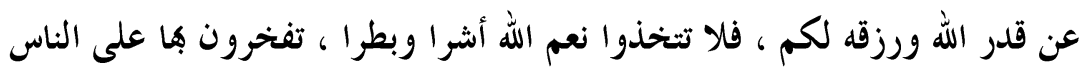

Janganlah kalian merasa bangga hati atas manusia terhadap segala sesuatu yang telah dikaruniakan kepada kalian, karena karunia itu bukanlah dari hasil usaha dan kegigihan kalian, karunia itu adalah ketetapan Allah SWT. dan rizkinya yang dikaruniakan kepada kalian, maka janganlah kalian menjadikan karunia Allah SWT. untuk berbuat keburukan dan saling menyombongkan antara manusia. Para Ulama telah menjelaskan bahwa tidak merasa gembira dengan karunia yang

${ }^{114}$ Sayyid Quthub, Fī Zhilāl Al-Quran, Juz 11, Jakarta: Gema Insani Press, 2007, Hlm. 174. 
(membagakan diri) terhadap nikmat Allah dimana ia melekatkannya terhadap dirinya. ${ }^{116}$

Kemudian Sayyid Quthub juga menjelaskan bahwa, "Meluaskan cakmwala pandangan. berinteraksi dengan alam raya, menggambarkan masa azab dan masa abadi, melihat aneka peristiwa selaras dengan aneka situasinya yang ditakdirkan dalam ilmu Allah dan yang ditetapkan dalam rancangan alam sem\&€ta ini, akan membuat jiwa lebih lapang, lebih besar, lebih teguh, dan lebih elastis dalam menghadapi aneka peristiwa yang terjadi tatkala jiwa menying' kap wujud manusia ini yang berjalan seirama dengan gerakan alam semesta.

Manusia akan berkeluh-kesah dan merasa terhina oleh berbagai peristiwa tatkala dia memisahkan dirinya dari alam ini dan tatkala memperlakukan berbagai peristiwa sebagai sesuatu yang baru, yang menohok wujud dirinya yang kecil. Namun, tatkala di dalam konsepsi dan perasaannya mengendap pemahaman bahwa dirinya dan aneka peristiwa yang dilaluinya, dilalui orang lain, dan dialami oleh dunia yang hanya bagaikan butiran atom padajagat raya ini telah ditakdirkan, dirancang, dan diketahui dalam ilmu Allah yang tersimpan, maka dia akan merasa tenang dan tenteram dalam menghadapi seluruh peristiwa takdir secara sama. Maka, dia takkan bersedih atas sesuatu yang menyedihkan dan mengguncangkannya.

Dia tidak bergembira atas suatu prestasi yang diperolehnya, sehingga membuatnya lalai dan terlena. Namun, dia berlalu bersama takdir Allah dengan kepatuhan dan kerelaan. Kerelaan seorang yang bijak yang memahami bahwa perkara yang telah terjadi merupakan sesuatu yang semestinya terjadi. Itulah derajat yang takkan dapat diraih kecuali oleh segelintir orang. Adapun kaum mukminin lainnya, maka yang dituntut dan' mereka ialah agar pedihnya kemudharatan atau suka citanya kebahagiaan tidak membuatnya keluar dari wilayah pengkonsentrasian diri kepada Allah, mengingat ini dan itu, dan bersikap proposional dalam menghadapi suka dan duka Akramah r.a. berkata, "Tiada seorang pun melainkan dia mengalami kegembiraan dan kesedihan. Namun, jadikanlah kegembiraan syukur dan kesedihan

116 Abdurrahman Ibn Nāshir As-Sa'diy, Taysīr Al-Karīm Ar-Rahmān F̄̄ Tafsīr Kalām Al-Mannān, Beirut: Risalah Publishers, 1423 H, Hlm. 842. 
sebagai kesabaran. Inilah jalan tengah Islam yang dimudahkan bagi Orang. orang stabil."

\section{c. Q.S. Al-Hadīd [57]: 20}

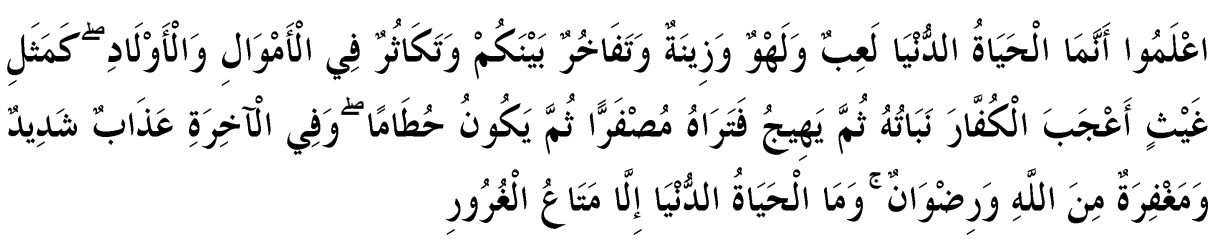

"Ketahuilah, bahwa sesungguhnya kehidupan dunia ini hanyalah permainan dan suatu yang melalaikan, perhiasan dan bermegahmegah antara kamu serta berbangga-banggaan tentang banyaknya harta dan anak, seperti hujan yang tanam-tanamannya mengagumkan para petani; kemudian tanaman itu menjadi kering dan kamu lihat warnanya kuning kemudian menjadi hancur. Dan di akhirat (nanti) ada azab yang keras dan ampunan dari Allah serta keridhaan-Nya. Dan kehidupan dunia ini tidak lain hanyalah kesenangan yang menipu."

Al-Qurthūbi menafsirkan kata lahwun adalah makan dan minum dengan mengambil penjelasan dari Qatādah, dan masih menurut AlQurthūbi dengan menyitir pendapat dari Mujāhid bahwa kata laĥwun adalah semua permainan yang dikenal oleh manusia. Kemudian disebutkan juga termasuk arti dari lahwwn adalah segala sesuatu yang melalaikan seorang atas akhirat, dan juga wanita (Al-Qurthubi). Dan kemudian pada ayat ini Allah SWT. menutup dengan kalimat "Dan kehidupan dunia ini tidak lain hanyalah kesenangan yang menipu.".

Ibn Al-Qayyim mengungkapkan ahli zuhud adalah seseorang yang mengeluarkan dunia dalam hatinya. Karena dunia adalah kesenangan yang menipu, maka tidak pantas jika ia bersemayam dalam hati ahli zuhud:

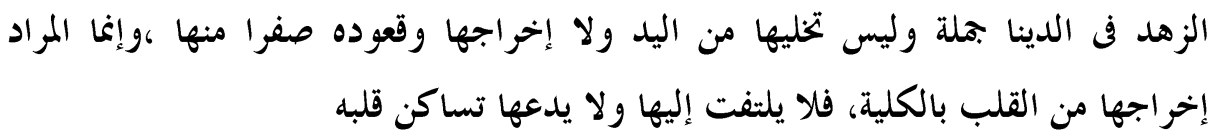

Zuhud pada dunia bukan mengosongkannya dari tangan seseorang, dan tidak mengeluarkan dunia dan mengosongkannya darinya, yang dimaksud dengan zuhud terhadap dunia adalah mengeluarkan dunia

${ }^{117}$ Sayyid Quthub, Fī Zhilāl Al-Quran, Juz 11, Jakarta: Gema Insani Press, 2007, Hlm. 174. 
dari hatimu, dan janganlah berpaling kepada dunia, dan jangan seseorang meniggalkannya untuk bersemayam dihatinya. ${ }^{118}$

Al-Qurthubi melanjutkan, hakikat manusia yang tertipu dengan dunia adalah manusia-manusia yang tidak beriman kepada Allah SWT. adapun bagi orang-orang yang beriman mereka menjadikannya sebagai saran untuk memasuki surgaNya.

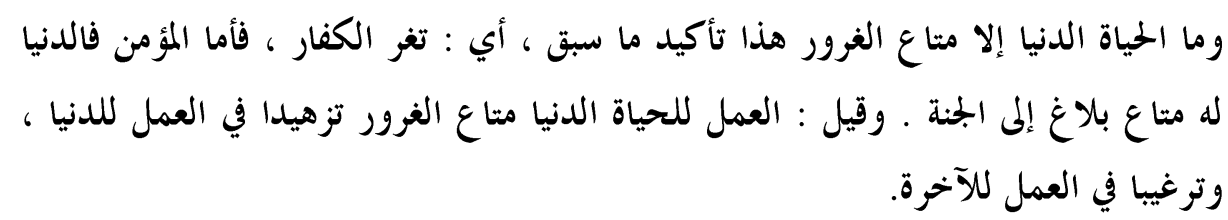

Adapun kehidupan dunia adalah kesenangan yang menipu, ini adalah penegasan pada kalimat sebelumnya, yaitu orang-orang kafir tertipu, adapun orang-orang beriman maka dunia baginya sebagai keindahan yang akan menyampaikannya ke Jannah, dan dikatakan sebuah amal dari kehidupan dunia yang menipu ini adalah zuhud dalam amal untuk dunia, dan semangat untuk amal menuju akhirat ${ }^{119}$

Mengenai ayat ini Sayyid Quthub mengungkapkan kata lugas untuk menjadi bekal atas setiap Muslim dalam mengarungi kehidupan ini, "Tatkala kehidupan dunia diukur dengan ukuran duniawi dan ditimbang dengan aneka timbangan duniawi, tampaklah pada mata dan rasa sebagai sesuatu yang besar dan mencengangkan. Namun, tatkala ia diukur dengan timbangan alam nyata dan ditimbang dengan timbangan akhirat, tampaklah sebagai sesuatu yang hina dan tidak berarti. Di sini dunia digambarkan demikian, sehingga ia tampak sebagai permainan anak-anak jika dikaitkan dengan kesungguhan yang ada di akhirat yang menjadi muara seluruh penghuni dunia setelah sebelumnya sebagai mainan kehidupan. Dunia merupakan permainan, sesuatu yang me lalaikan, perhiasan, sarana bermegah megah, dan sarana untuk berbangga bangga. Inilah hakikat yang ada di balik setiap kesungguhan yang menyita perhatian dan setiap kepentingan yang melenakan. Kemudian Al-Qur'an mengilustrasikan dunia dengan contoh yang mengesankan bahwa dunia itu seperti hujan yang tanam-tanamannya mengagumkan para petani ". Di sini al-kuffar berarti petani.

${ }^{118}$ Fathi Majdi Al-Sayyid, Al-Zuhd : Li Al-Imām Abi 'Abd Allah Al-Qurthubī, , Mesir: Maktabah Al-Shahābah, 1408 H. Hlm. 20.

119 Abu Abdillah Muhammad Ibn Ahmad Ibn Abi Bakr Al-Qurthubi, Jāmi' AlAhkāam Al-Qur'ān, Beirut: Ar-Risālah Publishers, 1428 H, Juz 20, hlm.262, Juz 20 
Secara lughawi, kafir berarti penanam, karena dia suka "menutupi dan menyelimuti" biji dalam tanah. Namun, pemilihan kata itu di sini juga sebagai sindiran atas kaum kafir yang terpesona oleh kehidupan dunia. "Kemudian tanaman itu menjadi kering dan kamu lihat warnanya kuning" karena telah dipanen. Tanaman itu memiliki batas akhir, cepat berakhir, dan batas akhirnya itu dekat. "Kemudian ia hancur." Seluruh rangkaian kehidupan berakhir dalam sosok dinamis seperti itu, yang berasal dari pemandangan yang biasa dilihat manusia. Dunia berakhir dalam pemandangan kehancuran. "Kemudian tanaman itu menjadi kening dan kamu lihat warnanya kuning" karena telah dipanen. Tanaman itu memiliki batas akhir, cepat berakhir, dan batas akhirnya itu dekat. "Kemudian ia hancur ." Seluruh rangkaian kehidupan berakhir dalam sosok dinamis seperti itu, yang berasal dari pemandangan yang biasa dilihat manusia Dunia berakhir dalam pemandangan kehancuran.

Adapun persoalan akhirat sungguh berbeda dari persoalan dunia. Suatu persoalan yang layak diperhitungkan, dicermati, dan dipersiapkan. "Dan di akhirat (nanti) ada azab yang keras dan ampunan dari Allah serta keridhaan-Nya" Akhirat tidak berakhir dalam sekejap seperti halnya dunia. Akhirat tidak berakhir dengan kehancuran seperti halnya tanaman yang telah mencapai batas akhirnya.

Akhirat merupakan alam kalkulasi, pembalasan, dan keabadian yang berhak dipentingkan. "Kehidupan dunia ini tidak lain hanyalah kesenangan yang menipu. " (Al-Hadīd: 20). Dunia itu sendiri merupakan kenyataan tatkala kalbu mencari hakikat dengan mendalam.

Ia merupakan hakikat yang Al-Qur'an tidak bermaksud memisahkan manusia dari kehidupan dunia dan tidak bermaksud supaya dia mengabaikan pengolahan dan penataannya, karena manusia diserahi pekerjaan ini.

Tujuan ayat itu ialah untuk meluruskan ukuran perasaan dan nilai-nilai psikologis serta mengatasi tipuan harta yang cepat sirna serta daya tariknya yang mengikat ke bumi. Pemutusan hubungan atas dunia yang diserukan dalam surah ini sangat diperlukan dalam rangka mengaktualisasikan keimanan yang dibutuhkan oleh setiap mukmin agar dia dapat mewujudkan keyakinannya, walaupun perwujudan itu menuntut supaya mengorbankan seluruh kehidupan dunia. Karena itu, Allah menyeru manusia supaya berkompetisi di arena pertandingan yang hakiki untuk meraih tujuan yang berhak dimiliki oleh pemenang. 
Tujuan yang menjadi akhir tempat kembali mereka; yang memastikan mereka tinggal di alam keabadian.

Kesenangan ini tidaklah memiliki substansi karena topangannya berupa tipuan dan kemayaan. Di samping itu, dunia pun melenakan dan melupakan, sehingga membawa pemiliknya kepada bayang-bayang yang menipu." 120

\section{d. Q.S. Al-Māidah [5]: 87}

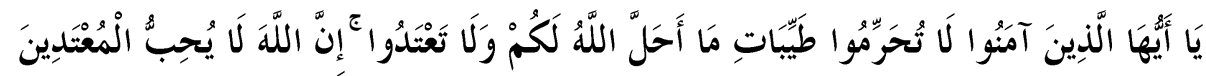

"Hai orang-orang yang beriman, janganlah kamu haramkan apa-apa yang baik yang telah Allah halalkan bagi kamu, dan janganlah kamu melampaui batas. Sesungguhnya Allah tidak menyukai orang-orang yang melampaui batas."

Al-Qurthūbi meriwayat dari sanad Al-Thabariy bahwa sebab turunnya dari ayat ini :

رجل أتى النبي صلى الله عليه وسلم فقال : يا رسول الله إين إذا أصبت من اللحم انتشرت

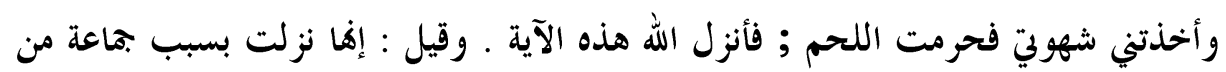

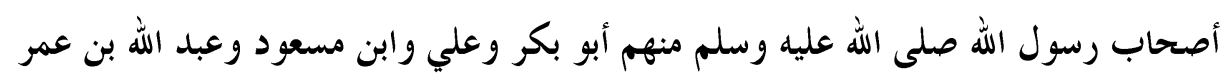

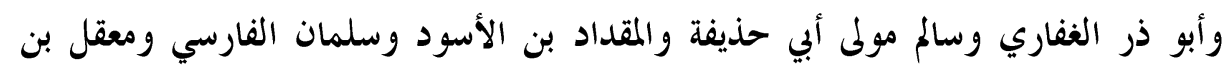

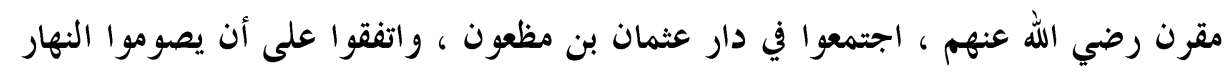

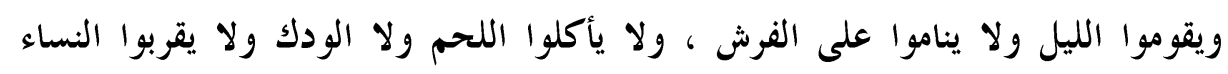

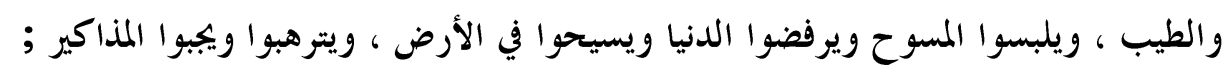
فأنزل الله تعالى هذه الآية والية

Seseorang datang kepada Nabi SAW. dan berkata : Wahai Rasulullah SAW. sesungguhnya aku mendapatkan bagian dari pembagian daging, dan aku mengambilnya dengan syahwatku, maka aku haramkan daging atas diriku, maka Allah SWT. menurunkan ayat ini. Dan juga dikatakan (tentang asbab al-nuzūl): ayat ini diturunkan dengan sebab adanya sekelompok sahabat Rasulullah SAW. diantara mereka ada Abu Bakar, 'Ali, Ibn Mas'ūd, Abd-Allah Ibn 'Umar, Abu Dzār Al-Ghifāri, Sālim

${ }^{120}$ Sayyid Quthub, F̄̄ Zhilāl Al-Quran, Juz 11, Jakarta: Gema Insani Press, Hlm. 171-172. 
bekas budak Abu Hudzaifah, Miqdād Ibn Al-Aswād, Salman Al-Fārisi, dan Ma'qil Ibn Muqrin, mereka berkumpul dirumah 'Utsmān Ibn Mazh'ūn, dan mereka bersepakat untuk berpuasa pada siang hari dan shalat malam pada malam hari tanpa tidur diatas kasur, dan mereka juga bersepakat untuk tidak memakan daging, dan juga tidak akan mendekati istri-istrinya dan memakai minyak wangi, dan mereka juga sepakat untuk memakai al-masūh, menolak dunia dan tidak menetap disebuah negeri, mereka merahibkan diri mereka dengan mengantungi alat zikir, maka Allah SWT. turunkan ayat ini. ${ }^{121}$

Tentang ayat ini Abu Ja'far menafsirkan :

قال أبو جعفر: يقول تعالم ذكره: يا أيها الذين صدَّقوا الله ورسوله، وأقرُّوا بعا جاءهم به مأه

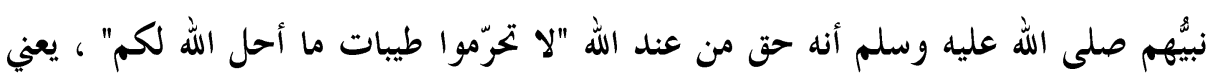
بـ "الطيبات" ، اللذيذات التي تشتهيها النفوس، وتميل إليها القلوب، فتمنعوها إيّاها،

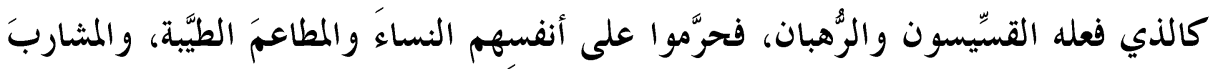

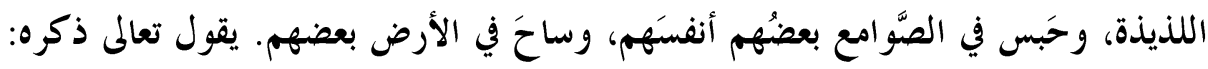

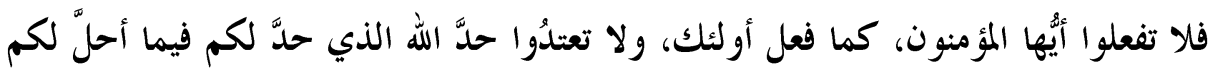

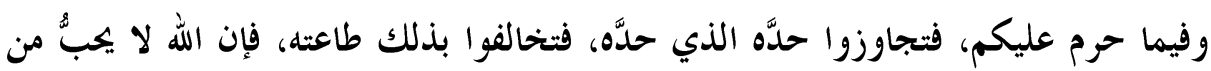

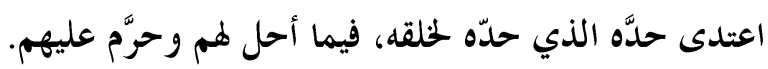

Firman Allah SWT. : Wahai orang-orang yang jujur kepada Allah SWT. dan RasulNya, dan mereka menetapkan terhadap segala sesuatu yang datang dari Nabi mereka, sesungguhnya Ia SAW. benar dari sisi Allah SWT. "Janganlah kalian mengharamkan yang baik-baik dari apaapa yang telah Allah SWT. halalkan bagi kalian" yaitu kata "yang baikbaik" adalah kelezatan-kelezatan yang diinginkan oleh jiwa, dan hati cendrung kepadanya, maka mereka mencegahnya, seperti perbuatan para pendeta, maka mereka haramkan atas diri-diri mereka terhadap wanita, makanan-makanan yang baik, minuman-minuman yang lezat, dan sebagian menahan menahan dari lambung sebagian mereka, serta sebagian mereka berjalan dibumi. Allah SWT. menyebutkan: maka janganlah kalian melakukannya wahai orang-orang mukmin, seperti perbuatan mereka, dan jangan melanggar batasan Alllah SWT. yang telah dibatasi bagi kalian, dari segala sesuatu yang yang telah Allah

${ }^{121}$ Abu Abdillah Muhammad Ibn Ahmad Ibn Abi Bakr Al-Qurthubi, Jāmi' AlAhkāam Al-Qur 'ān, Beirut: Ar-Risālah Publishers, 1428 H, Juz 8, hlm.115. 
SWT halallkan bagi kalian, dan yang telah haram bagi kalian, sehingga kalian melampui batasan yang telah ditetapkan oleh Allah SWT, sehingga kalian menyelisihinya dengan itu adalah ketaatannya. Sesungguhnya Allah SWT. tidak mencintai orang-orang yang melanggar batasan yang telah Ia SWT. batatasi atas makhluknya, dari apa-apa yang halal juga haram. ${ }^{122}$

Adapun Ibn 'Âsyūr menjelaskan tentang bolehnya meninggalkan sesuatu dalam baik makan, minum, pakaian dan hal-hal yang berkaitan dengan dunia dalam upaya untuk melatih jiwa agar tidak memiliki ketergantungan atas hal tersebut selama tidak sampai mengharamkan secara mutlak.

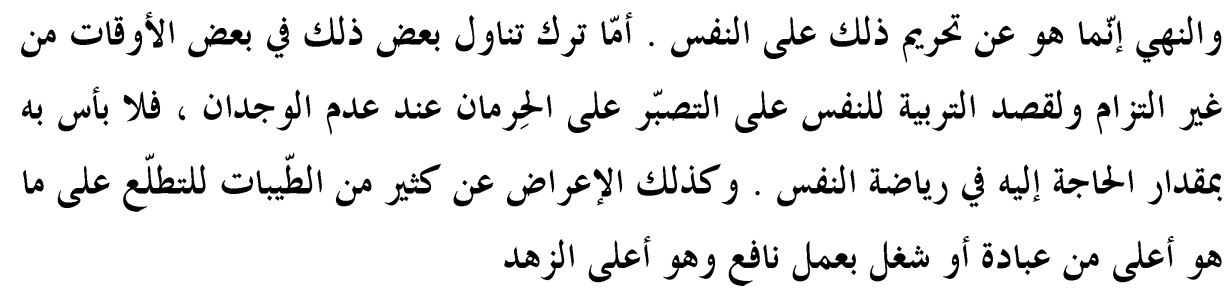

Dan larangannya hanya dalam pengharaman jiwa atasnya. Adapun meninggalkan untuk memakan dari sebagaian itu disebagian waktuwaktu selama tidak dikuatkan dan untuk maksud pembelajaran terhadap jiwa untuk sabar atas keharaman, maka hal tersebut tidak mengapa dengan ukuran kebutuhan atasnya didalam pelatihan terhadap jiwanya. Dan begitu juga berpaling dari kebayakan yang baik-baik untuk lebih menfokuskan atas ibadah, atau menyibukan dengan amal yang bermanfaat maka hal tersebut lebih tinggi kedudukannya diatas zuhud. ${ }^{123}$

Kemudian As-Sa'di menafsirkan :

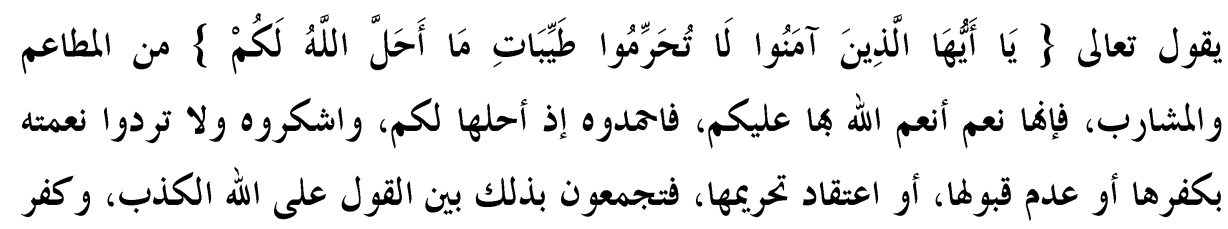

122 Basyar 'Awwadh Ma'rūf.et.al., Tafsīr Ath-thabari Min Kitābihi Jāmi' AlBayān Ta'wūl Ayy Al-Quran, Beirut : Muassasah Ar-Risālah, 1415 H, Hlm. 151.

${ }^{123}$ Muhammad Thāhir Ibn 'Âsyūr, At-Tahrīr Wa Tanwīr, Juz 9,Tūnis: Li Ad-Dār At-Tūnisiyyah Li An-Nasyr, 1984, hlm. 15. 


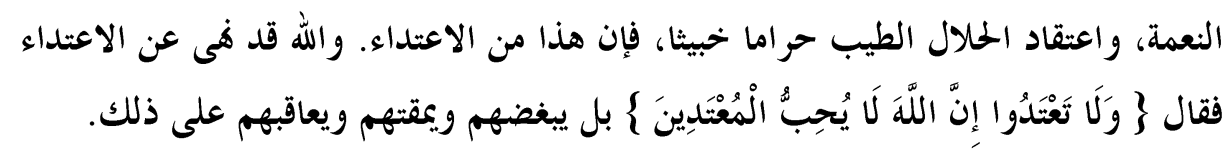

"Hai orang-orang yang beriman, janganlah kamu haramkan apa-apa yang baik yang telah Allah halalkan bagi kamu," dari makanan dan minuman, karena ia adalah nikmat Allah yang Allah berikan kepadamu. Bersyukur dan pujilah Dia, karena Dia telah menghalalkannya untukmu, jangan menolaknya dengan mengkufurinya atau tidak menerima" nya atau meyakini keharamannya, karena dengan itu kamu menggabungkan antara berdusta atas Nama Allah dengan mengkufuri nikmatNya dan meyakini yang halal lagi baik sebagai yang haram lagi buruk; karena ini termasuk melanggar batas, dan Allah melarang perbuatan melampaui batas. Dia berfirman, "Dan janganlah kamu melampaui batas. Sesungguhnya Allah tidak menyukai orang-orang yang melampaui batas," bahkan Dia membenci, memurkai, dan akan menghukum mereka atas hal itu.". ${ }^{124}$ As-Sa'di menekankan agar setiap mukmin dia mau menerima semua kenikmatan yang telah dihalalkan oleh Allah SWT. serta tidak menolaknya karena hal yang demikian merupakan bentuk pembakangan atas perintah Allah SWT. agar setiap mukmin memakan makanan yang halal lagi baik.

Faidah dari ayat ini adalah tidaklah dimaksud zuhud adalah membeci dunia, adalah Sulaiman dan Daud Alaihima Al-Salām diantara ahli zuhud pada zaman mereka berdua, keduanya memiliki harta, kerajaan, dan Istri, bahkan Nabi Muhammad SAW. adalah manusia yang paling zuhud secara mutlak namun Nabi SAW. memiliki istri sembilan orang. Dan juga Ali Ibn Abi Thālib, Abdurrahmān Ibn Al'Auf, Zubair dan 'Utsman adalah para ahli zuhud dan mereka tetap memeliki harta bahkan diatara mereka memiliki harta yang banyak. Imam Ahmad pernah ditanya tentang sesorang ahli zuhud apakah boleh memiliki harta maka dijawab oleh Imam Ahmad;

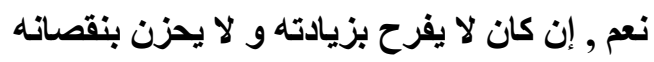

"Iya jika ia tidak bergembira dengan bertambahnya harta dan tidak merasa sedih dengan berkurangnya harta." 125

124 Abdurrahman Ibn Nāshir As-Sa'diy, Taysīr Al-Karīm Ar-Rahmān F̄̄ Tafsīr Kalām Al-Mannān, Beirut: Risalah Publishers, 1423 H, Hlm.223.

125 Sa'̄̄d 'Abd Al-'Azhīm, Al-Zuhd : Izhad F̄̄ Al-Dunya Yuhbibuka Al-Nās, Iskandariyah: Dār Al-Īmān, 2004 M , Hlm.5. 
Maka dari empat ayat beserta tafsirnya, maka dapat diambil konsep zuhud dalam Al-Quran yaitu, kesederhanaan, kesabaran, wara', dan keseimbangan (tawāzun)

\section{Penutup}

Zuhud merupakan cara hidup yang mulia, dimana seluruh orang salih telah menjalani, dan dengan begitu hal tersebut menjadi teladan bagi orang-orang setelahnya.

Untuk menempuh jalan zuhud Al-Quran telah memberikan rambu-rambu dan panduannya agar setiap manusia tidak salah dalam memahami jalan hidup zuhud. Diantara ayat-ayat yang berkaitan dengan zuhud adalah pada Q.S. Al-Hadīd [57] : 20 dan 23, Q.S. AlQashāsh [28]: 77, dan Q.S. Al-Mā idah [5]: 87.

Adapun hasil penelitian pada makalah ini dapat mengeluarkan empat sikap zuhud dalam Al-Quran; kesederhanaan, kesabaran, wara' dan keseimbangan hidup (tawāzun)

Sebenarnya masih banyak lagi ayat-ayat yang dapat dieksplor untuk diambil faidah hakikat zuhud, namun dikarenakan keterbatasan waktu, kajian tentang zuhud dalam Al-Quran kami cukupkan, saran kami agar kajian ini dapat dikembangkan oleh para pemateri lainnya. Dan harapan kami agar makalah dapat bermanfaat untuk kaum Muslimin. 


\section{Daftar Pustaka}

Abd Al-'Azhīm, Dr. Sa'īd ', Al-Zuhd : Izhad F̄̄ Al-Dunya Yuhbibuka Al-Nās, Iskandariyah: Dār Al-Īmān, 2004

Al-Qurthubi, Abu Abdillah Muhammad Ibn Ahmad Ibn Abi Bakr, Jāmi' Al-Ahkāam Al-Qur 'ān, Beirut: Ar-Risālah Publishers, Juz $8.1428 \mathrm{H}$.

Al-Sindî, Abdul Qadir Ibn Habibullah, Al-Tashawwuf Fi Mîzan AlBahts Wa Al-Tahqîq Wa Al-Râd 'Alâ Ibn Al-'Arabiy Al-Shūfiy Fî Dhaw`i Al-Kitâb Wa Al-Sunnah, Madinah : Maktab Ibn AlQayyim, $1410 \mathrm{H}$.

As-Sa'diy, Abdurrahman Ibn Nāshir, Taysīr Al-Karīm Ar-Rahmān F̄̄ Tafsīr Kalām Al-Mannān, Beirut: Risalah Publishers, $1423 \mathrm{H}$.

Aziz, Safrudin, M.Pd.I, Pendidikan Seks Berbasis Terapi Sufistik Bagi LGBT, Penerbit : ernest, 2017, Kendal.

Banâni, Dr. Ahmad Ibn Muhammad, Mawqifu Al-Imâm Ibn Taymiyyah Min Al-Tashawwuf wa Al-Shüfiyyah, Riyadh : Dâr Al-Ilm, 1406 H.

Dimyati, M.Kom.I, Drs. Ahmad, Dakwah Personal: Model Dakwah Kaum Naqsanbadiyah, Yogyakarta: Penerbit Deepublish, 2016.

Dewi, Rani Anggraini, Menjadi Manusia Holistik, Jakarta : Penerbit Hikmah, 2006.

Himawijaya, Mengenal Al-Ghazali For Teens: Keraguan Adalah Keyakinan, Bandung : Dar! Mizan , 2004.

Huda, Sokhi, Tasawuf Kultural: Fenomena Shalawat Wahidiyah, Yogyakarta: LKiS Yogyakarta, 2008.

Hitti, Philip Khuri, History Of The Arabs, Jakarta : Serambi, 2006, Terjemahan.

Ibrahim, Muhammad Zaki, Tasawuf Hitam Putih, Solo : Penerbit Tiga Serangkai, 2006, cet. 2.

Ibn 'Âsyūr, Muhammad Thāhir, At-Tahrīr Wa Tanwīr, Juz 9, Tūnis: Li Ad-Dār At-Tūnisiyyah Li An-Nasyr, 1984 
Isa, Abdul Qodir, Hakikat Tasawuf, Jakarta: Qisthi Press, 2005.

Kafie, Jamaluddin, Tasawuf Kontemporer, Jakarta: Mutiara Al-Amin Prenduan, 2003.

Ma'rūf, Dr. Basyar 'Awwadh.et.al., Tafsìr Ath-thabari Min Kitābihi Jāmi' Al-Bayān Ta'wīl Ayy Al-Quran, Beirut : Muassasah ArRisālah, $1415 \mathrm{H}$.

Muslim Ibn Hajjaj Al-Qusairiy An-Naisabūri, Shah̄̄h Muslim, Riyādh: Bait Al-Afkar, $1419 \mathrm{H}$.

Salahudin, Asep, Abah Anom: Wali Fenomenal Abad 21 \& Ajarannya, Jakarta: Penerbit Noura Books, 2013.

Solikhin, KH. Muhammad, Filsafat dan Metafisika Dalam Islam: Sebuah Penjelajahan Pengalaman Mistik, Dan Perjalan Aliran Manunggaling Kawula Gusti, Yogyakarta: Penerbit Narasi, 2008.

Solikhin, K.H. Muhammad, Menyatu Diri Dengan Ilahi, Yogyakarta : Narasi, 2010.

Triana, Rumba, Tafsir Ayat-ayat Jihad Dalam Al-Quran, Bogor: Jurnal Al-Tadabbur: Jurnal Ilmu Al-Quran dan Tafsir ,2017.

Quthub, Sayyid, F̄̄ Zhilāl Al-Quran, Jakarta: Gema Insani, Press. 2004

Zhâhir, Ihsan Ilâhi, Al-Tashawwuf Al-Mansya`Wa Al-Mashâdir, H, Pakistan, Idârah Tarjaman Al-Sunnah. 1406 H.

Zhāhir, Ihsan Ilāhi, Darah Hitam Tasawuf : Studi Kritis Kesesastan Kaum Sufi, Jakarta: Darul Haq, cet.3, 2006 M.

Zhâhir, Ihsan Ilâhi, Al-Tashawwuf Al-Mansya 'Wa Al-Mashâdir Pakistan : Idârah Tarjaman Al-Sunnah, 1406 H.

,Majalah Cahaya Nabawi : Memahami Tasawuf, Edisi : 155, Desember 2016, hlm 27-28 


\section{$\therefore 0^{\circ}$

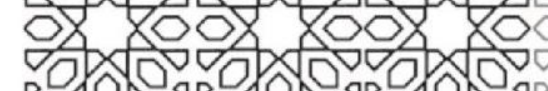

D.

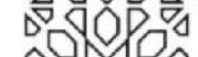

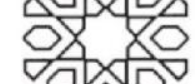

DO OSO

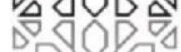

o) 